133 筋萃縮性側索硬化症における器下障害 について

○吉田 哲二, 平野 実, 進 武幹 大久保 洋, 吉田 義一 (久留米大)

本症は上位運動ニューロンと下位運動ニューロンが 選択的江变性し進行性の経過を示すことを特徴とする

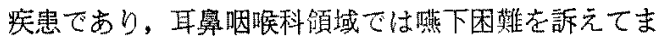
れに遭遇するが，㘃下障害についての詳細な報告はほ とんどみられない。

研究の目的：自験例 5 例について燕下運動を $\mathrm{X}$ 線 テレビで観察し，同時汇燕下に関与する筋群より筋電 図を記録するととにより，そのメ力二ズム老解明し， 本症の紧下障害に対する治療法を確立することにあ る.

研究方法：X線テレビ透視下汇流動物㧍よび固

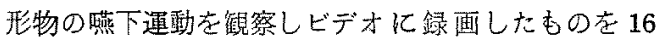
$\mathrm{mm}$ 映画フイルムに変換し, 䀢頭挙上之咽頭管の収 縮状態，哭下速度などを分析した。また筋電図の記録 には有鈎電極を用い下咽頭収縮筋, 舌骨上筋群などの 作動様式を同時誘導し比較榆討した。

研究成續：本症の主な筋電図所見は，甲状咽頭筋

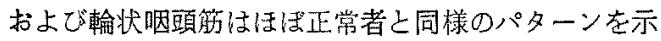
す。オトガイ舌骨筋は特徵ある变化がみられ，特に固

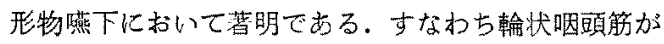

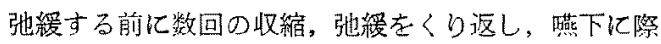
して甲状咽頭筋上ほ涩同時に強い収縮を示す。また燕 下終了後も再で数回の収縮, 弛緩をくり返す。乙れは 内・外舌筋が菜縮しているた好の悲下第 1 相の障害に よると考元られる。 また 1 例では輪状咽頭筋において

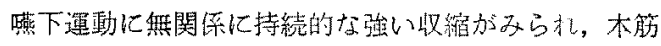
にスパスム様所見が観察された。

透視所見の特徽は器下第 1 相の障害であり舌萎縮に よる舌運動障害および軟口蓝の挙上障害に上る暴咽腔 閉鎖不全が覞察された。第 2 相の障害住食道入口部の

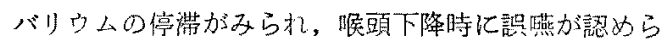
机た。

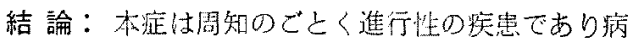
期に上り舆下障害の程度の差がみらるが主な所見は次 のごこくである。

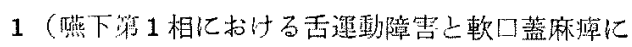
よる鼻咽腔鹏銷不全である。

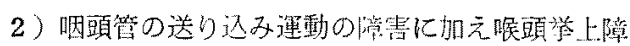
害がみら忆る。

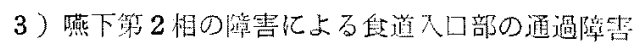
による䛊嬿かるるら机。

\section{ForEstIER 氏病と䕒下障害}

○井上 鉄三, 攞田 政道, 渡辺 英男
鈴 博 (国立病院医療センター)

FORESTIEN $か$ "Senile ankylosing hyperostosis of the spine" として 1950 年に発表して以来, 本症の燕下運動におよぼす影響がクローズアップされ てき地．古くは WENZEL と OPPENHEIMER 加別個 飞 1824 年に，ま圷 BECHTEREW が 1844 年に頸椎体 の肥厚, 增殖による蟔下障害を報告している. 最近で \& ankylosing hyperostosis of the spine (FoRESTIER 1971）または vertebral osteophytosis (MEEKS 1973) が一般病名として用いられている.

病理学的には, cortex 下の骨組織の增殖が単一ま たは数個の頸椎体におよび, 前方突出が著明上なり, 食道在王迫している像が観察される。

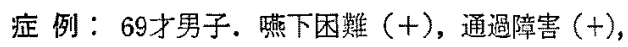
呼吸困難 $(-)$, 発声障害 $(-)$. X線にて著明なI VII頸推体肥厚・前方㔖出. 他の部分の骨変化はない.

筋電図検查では, 異常高・低電位 $(+)$, 脱神経電 位 $(-)$, 燕下パターン正常.

與下時に, 頸部食道の圧迫に上る通過障害が著明。

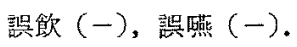

手術術式：気管切開施行. 右側頸部切開. 胸羦乳 㔖筋中央剥離後, 啹頭・気管を左方へ压迫. Cの祭, 反回神経は絶対損傷せぬようにする. 食道は左方へ偏 位している，頸椎体に到達，II〜叫までを充分な視野 のもとに露山する。

II〜VI頸椎の骨膜に正中切開を加え，肥厚增殖した 頸椎体の前面を露出する，平ノミにて頸椎体の増殖部 を少しずつ削除し，充分に平坦になるまで削除する。 特に上限 (I頙椎) お上び下限 (VII頸椎) の部分に突 出が残らない上うに留意する。かなりの出血がある が, bone wax で容易に止血可能である。

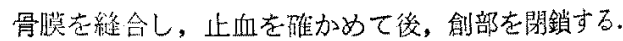
注意すべきは，頸部食道・下咽頭の神経線維は可及 的少箱国に, また反回神経・迷走神経等は絶対提賃し てはならない。

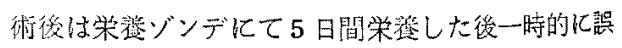
飲はむつたが，4〜5日にて回復し，術後10日目に は正常に器下可能となり通滑障害はまつたく消失し た. 